Tohoku J. exp. Med., 1973, 110, 181-189

\title{
Action of Cytochalasin B on the Contraction of Smooth Muscle of Guinea Pig Taenia Coli, Vas Deferens and Rat Uterus
}

\author{
Takeo Maruyama, Junichiro Nagasawa and Taizo Suzuki \\ Department of Applied Physiology, Tohoku University School \\ of Medicine, Sendai
}

\begin{abstract}
Maruyama, T., Nagasawa, J. and Suzurr, T. Action of cytochalasin $B$ on the contraction of smooth muscle of guinea pig taenia coli, vas deferens and rat uterus. Tohoku J. exp. Med., 1973, 110 (2), 181-189 — Effect of cytochalasin $B(C B)$ on in vitro contractile response of smooth muscle preparations of guinea pig taenia coli, vas deferens and estrogen treated rat uterus were investigated. In all these preparations, CB ( 1 to $10 \mu \mathrm{g} / \mathrm{ml}$ ) caused prompt, significant and reversible inhibition of contraction. Tetrodotoxin (TTX) was used to block the intramural nerve activity of these preparations. In the presence of TTX, CB still inhibited the contraction of taenia coli and uterine strip, but it (10 to 50 $\mu \mathrm{g} / \mathrm{ml}$ ) did not inhibit the direct muscular contraction of vas deferens. It was concluded from these results that in taenia coli and in myometrium, CB acts directly on smooth muscle cells and inhibits contraction, but in vas deferens, inhibitory effect of $\mathrm{CB}$ is almost entirely exerted through the inhibition of neural transmitter release from hypogastric nerve endings in this tissue. - smooth musele contraction; cytochalasin B; tetrodotoxin.
\end{abstract}

Cytochalasin B (CB) is a metabolite of the mold (Helminthosporium dematioideum) and is known to act on various cells through disruption of contractile microfilament system (Carter 1967).

Schroeder (1970) first reported that in cleaving sea-urchin egg, CB caused cessation of cleavage and formation of multi-nucleated cell as a result of disappearence of microfilaments in the cell.

Wessells et al. (1971) examined the effects of CB on a variety of cells that are supposed to function with the participation of the intracellular contractile microfilament system and concluded that almost in every instance CB inhibited the cell function through disruption of microfilament morphology.

Now there are an increasing number of evidences in the secretory cells such as pancreatic $\beta$-cell (Orci et al. 1972), anterior pituitary (Schofield 1971) and mast cells (Orr et al. 1972) that CB alters profoundly the mode of secretion possibly through the same mechanism as in other cells. And this is taken as one of the strong evidences that secretory process in these cells involves microfilament system present at the secretory sites.

The microfilament system in some of the CB sensitive cells are known to

Received for publication, October 31, 1972. 
contain actin-like substance which binds heavy meromyosins (Ishikawa et al. 1969; Allison et al. 1971). In this respect it is most interesting whether CB acts directly upon the actomyosin systems of various contractile tissues such as skeletal, cardiac and smooth muscle. The reports so far appeared in this field are rather fragmentary and no systematic attempt of tension measurement was carried out.

The aim of the present experiment is to see the effect of $\mathrm{CB}$ on various types of smooth muscle, since this tissue is different in many aspects from skeletal muscle (Burnstock 1970). One of the main morphological features of smooth muscle is the lack of distinct array of myosin and actin filaments which is commonly seen in skeletal muscle. In this respect, the arrangement of contractile filaments in smooth muscle is somewhat similar to developing embryonic cells where the action of $\mathrm{CB}$ is most prominent.

We are also interested in separating the action of $\mathrm{CB}$ on smooth muscle cell itself and intramural autonomic endings, because it is quite possible that $\mathrm{CB}$ acts specifically on one or other of these elements.

\section{Methods}

Male guinea pigs weighing 200 to $300 \mathrm{~g}$ were used in this experiment. After ether anesthesia, guinea pig abdomen was opened and taenia coli and vasa deferentia were excised. In some experiments, hypogastric nerve was carefully dissected and taken together with vas deferens. To obtain estrogen dominated rat uterus, female albino rats weighing about $200 \mathrm{~g}$ were injected with a daily dose of $20 \mu \mathrm{g}$ of estradiol benzoate for 5 days.

Muscle strips about $2 \mathrm{~cm}$ long were incubated in organ bath which contained, $50 \mathrm{ml}$ of modified Krebs solution, which has the following composition; $\mathrm{NaCl} 120.9 \mathrm{mM}$, $\mathrm{KCl}$ $5.9, \mathrm{CaCl}_{2} 2.5, \mathrm{MgCl}_{2}$ 1.2, $\mathrm{NaHCO}_{3}$ 15.5, $\mathrm{NaH}_{2} \mathrm{PO}_{4}$ 1.2, and glucose 11. The solution was bubbled constantly by a gas mixture of $5 \% \mathrm{CO}_{2}$ and $95 \% \mathrm{O}_{2}$ and $\mathrm{pH}$ was adjusted to 7.4 at $37^{\circ} \mathrm{C}$.

Supramaximal electrical field stimulation (ac $50 \mathrm{hz}$, duration 5 sec, strength $2 \mathrm{~V} / \mathrm{cm}$, unless otherwise stated) was applied every $3 \mathrm{~min}$ by a pair of silver plate immersed in the organ bath. Tension development was measured by Grass FT 10 or FT 03 force-displacement transducer and recorded on Grass model 5 polygraph.

Stock solution of CB (Imperial Chemical Industries Ltd) was made up as $1 \%$ solution in dimethylsulfoxide (DMSO) and was diluted directly in the organ bath to obtain final concentrations of 1 to $50 \mu \mathrm{g} / \mathrm{ml}$. To eliminate any effect of solvent, DMSO was previously included in all solutions at $2 \%$ concentration. Further addition of 0.2 to $1.0 \%$ of DMSO, that corresponded to the amount of DMSO introduced together with CB, did not cause any appreciable change in the contraction height of all the smooth muscles used in this experiment. Tetrodotoxin (TTX, Sankyo Co.) was freshly prepared from stock solution just prior to use.

\section{Results}

\section{Action of $C B$ on guinea pig taenia coli}

Pretreatment of taenia coli with $2 \%$ DMSO caused a slight increase in contraction height evoked by electrical stimulation, but it became constant after $30 \mathrm{~min}$ of DMSO application and further addition of up to $1 \%$ DMSO did not cause any discernible change in contractile response. Usually spontaneous contraction of 


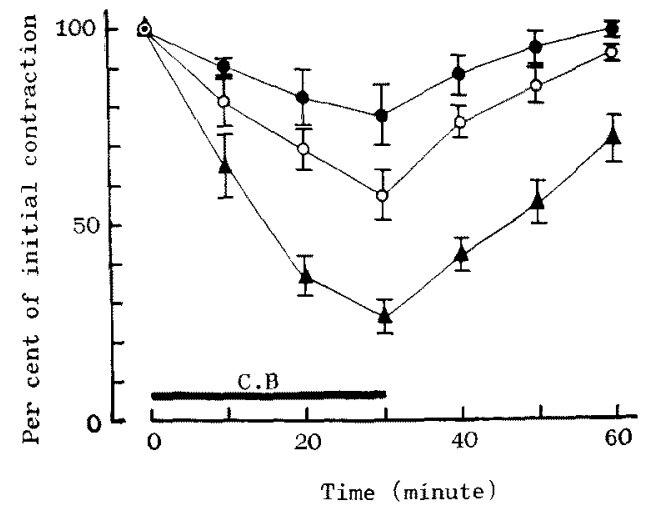

Fig. 1. Time course of inhibition and recovery of contraction of guinea pig taenia coli by cytochalasin B. Contraction height is expressed as percentage of control value prior to drug application. CB was applied for initial $30 \mathrm{~min}$ and followed by wash out with fresh Krebs solution. CB concentration; - - $5 \mu \mathrm{g} / \mathrm{ml},(\mathrm{N}=5) ; 0-010 \mu \mathrm{g} / \mathrm{ml}$, $(\mathrm{N}=6) ; \ldots 50 \mu \mathrm{g} / \mathrm{ml},(\mathrm{N}=5)$. Vertical bars indicate standard errors.

TABLE 1. Effect of $C B$ on contractile response of various smooth muscle tissues

\begin{tabular}{|c|c|c|c|c|}
\hline \multirow{2}{*}{ Preparation } & \multirow{2}{*}{$\begin{array}{c}\text { Dose of CB } \\
(\mu \mathrm{g} / \mathrm{ml})\end{array}$} & \multicolumn{3}{|c|}{ Contraction height ( $\%$ of control) } \\
\hline & & $10 \min$ in $C B$ & $30 \mathrm{~min}$ in $\mathrm{CB}$ & Wash out $30 \mathrm{~min}$ \\
\hline $\begin{array}{l}\text { Guinea pig } \\
\text { taenia coli }\end{array}$ & $\begin{array}{c}1 \\
5 \\
10 \\
50 \\
\operatorname{TTX}\left(1 \times 10^{-7}\right) \\
+10\end{array}$ & $\begin{array}{l}94.2 \pm 2.6 \\
90.4 \pm 2.3 \\
81.3 \pm 5.9 \\
64.9 \pm 7.8 \\
88.7\end{array}$ & $\begin{array}{l}85.5 \pm 2.3 \\
77.7 \pm 7.5 \\
58.1 \pm 7.4 \\
26.1 \pm 4.4 \\
55.8\end{array}$ & $\begin{array}{l}99.9 \pm 1.1 \quad(6) \\
98.9 \pm 2.0(5) \\
94.6 \pm 2.3(6) \\
70.4 \pm 8.3 \quad(5) \\
96.9\end{array}$ \\
\hline Rat uterus & $\operatorname{TTX}\left(1 \times 10^{-7}\right)$ & $\begin{array}{l}85.5 \\
83.6\end{array}$ & $\begin{array}{l}62.2 \\
63.3\end{array}$ & $\begin{array}{l}96.3(3) \\
97.8(2)\end{array}$ \\
\hline $\begin{array}{l}\text { Guinea pig } \\
\text { vas deferens }\end{array}$ & 10 & 78.8 & 52.4 & $92.4(3)$ \\
\hline
\end{tabular}

Numbers in parentheses are numbers of experiments. \pm Standard error.

In this table, contraction height at 10 and $30 \mathrm{~min}$ of $\mathrm{CB}$ application, and that after $30 \mathrm{~min}$ of wash out are shown. Contraction heights are expressed as percentage of control value.

taenia coli was also very effectively eliminated by DMSO.

Cytochalasin $\mathrm{B}$ decreased the contraction height of taenia coli at a concentration of $1 \mu \mathrm{g} / \mathrm{ml}$, but the inhibitory effect was most obvious at $10 \mu \mathrm{g} / \mathrm{ml}$ (Fig. 1 and Table 1), which is the standard inhibitory dose of CB in many other tissues.

Inhibitory effect of CB appeared as soon as the drug was applied, and it reached a plateau usually after about $20 \mathrm{~min}$ and showed no further change so long as the drug was present. At the maximal inhibition, the contraction height was $86 \%$ at $1 \mu \mathrm{g} / \mathrm{ml}, 58 \%$ at $10 \mu \mathrm{g} / \mathrm{ml}$ and $26 \%$ at $50 \mu \mathrm{g} / \mathrm{ml}$ of $\mathrm{CB}$ compared with the initial 

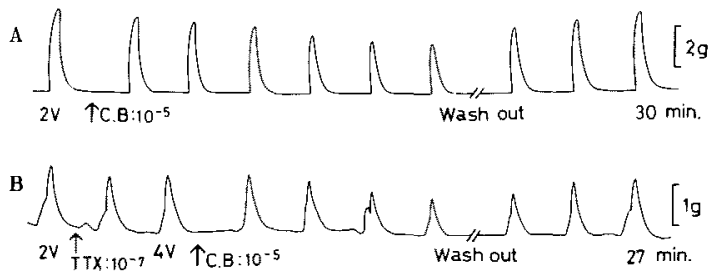

Fig. 2. Contractile response of guinea pig taenia coli. Preparations were stimulated electrically every $3 \mathrm{~min}$.

A: At the arrow $1 \times 10^{-5} \mathrm{~g} / \mathrm{ml} \mathrm{CB}$ was applied. Contraction heights decreased as soon as the drug was given. After $30 \mathrm{~min}$ of wash out, recovery was almost complete. B: After $1 \times 10^{-7} \mathrm{~g} / \mathrm{ml}$ TTX, contraction height decreased about by $10 \%$, but it remained constant in spite of the increase of stimulation strength to $4 \mathrm{~V} / \mathrm{cm}$ (at the third contraction from left). $\mathrm{CB}\left(1 \times 10^{-5} \mathrm{~g} / \mathrm{ml}\right)$ still reversibly inhibited the contraction of taenia coli in the presence of TTX.

contraction height (Table 1).

Wash out of $\mathrm{CB}$ promptly recovered contractile response. Recovery was complete at low concentrations of $\mathrm{CB}$ (up to $10 \mu \mathrm{g} / \mathrm{ml}$ ), provided wash out started within $30 \mathrm{~min}$ of drug application. In higher concentrations, recovery was incomplete; for instance, in the case of $50 \mu \mathrm{g} / \mathrm{ml}$ of $\mathrm{CB}$, recovery was only $70 \%$ of the control even after prolonged wash out.

Fig. 1 shows the cumulative results of the CB effect on taenia coli. This figure shows clearly the dose dependent inhibition of contraction and its reversible nature. From this figure and Table 1, inhibitory effect of $\mathrm{CB}$ on the contraction of taenia coli was quite evident.

Taenia coli preparation contains both excitatory and inhibitory nerve fibers and many ganglion cells that altogether form myenteric (Auerbach) plexus. Since CB is known to inhibit many secretory systems, it is very important to see whether the inhibition of contraction is due to direct inhibition of contractile system or indirect inhibition of transmitter release at the intrinsic nerve terminals.

Tetrodotoxin was used to distinguish this point, since this drug is known to suppress specifically the excitability of nerve and skeletal muscle but not that of smooth muscle (Kuriyama et al. 1966). Addition of $1 \times 10^{-8} \mathrm{~g} / \mathrm{ml}$ of TTX to taenia coli, which was sufficient to suppress the intramural nerve activity of guinea pig vas deferens (see Fig. 4-C), caused about a $10 \%$ decrease of contraction, but further addition of $1 \times 10^{-7} \mathrm{~g} / \mathrm{ml}$ of TTX or the increase of electrical stimulus strength showed no further change in contraction height. From this, the initial decrease of contraction was considered to be due to the suppression of excitatory nerve, and in the presence of a sufficient amount of TTX, nervous elements of taenia coli could be effectively eliminated.

In the presence of $1 \times 10^{-7} \mathrm{~g} / \mathrm{ml}$ of TTX, addition of $10 \mu \mathrm{g} / \mathrm{ml}$ of CB still caused inhibition of contraction (Fig. 2-B), and the time course and the rate of maximum suppression were completely the same as in the control experiment (Table 1). From this, it was concluded that $\mathrm{CB}$ inhibits directly the contractile elements of taenia coli, and intrinsic nerves are not involved in this response. 

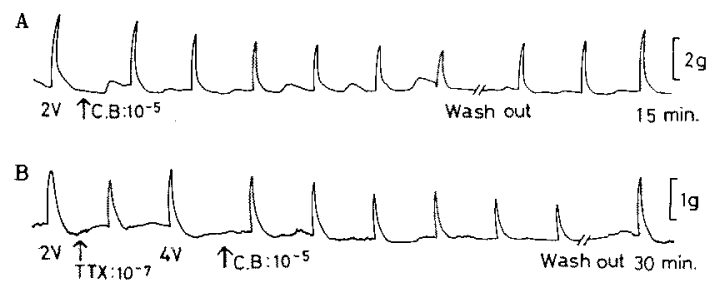

Fig. 3. Contractile response of estrogen pretreated rat uterus.

A: $1 \times 10^{-5} \mathrm{~g} / \mathrm{ml} \mathrm{CB}$ inhibited contraction, it was recovered by $15 \mathrm{~min}$ of washing.

B: After $1 \times 10^{-7} \mathrm{~g} / \mathrm{ml}$ of TTX, CB $\left(1 \times 10^{-5} \mathrm{~g} / \mathrm{ml}\right)$ still eaused inhibition. Recovery was complete at $30 \mathrm{~min}$ of wash out.

\section{Action of $C B$ on rat myometrium}

The spontaneous contraction of uterine strip of estrogen pretreated rat was very strong, and preincubation of the tissue in $2 \%$ DMSO could not completely suppress spontaneous contractions.

The inhibitory effect of $\mathrm{CB}$ in this tissue was very similar to that in taenia coli (Fig. 3-A). After $20 \mathrm{~min}$ of $10 \mu \mathrm{g} / \mathrm{ml}$ of $\mathrm{CB}$, contraction was $62 \%$ of initial value (Table 1). The interesting finding in this tissue was that the spontaneous contraction was also inhibited by the same degree as electrically stimulated contractions.

In the presence of TTX $\left(1 \times 10^{-7} \mathrm{~g} / \mathrm{ml}\right), 10 \mu \mathrm{g} / \mathrm{ml}$ of CB still caused contraction inhibition just to the same extent as in the control (Fig. 3-B). In this respect, uterine strip behaved just like taenia coli, and CB seemed to exert inhibitory effect directly on smooth muscle cells.

\section{Action of $\mathrm{CB}$ on guinea pig vas deferens}

The tissue of vas deferens is different from taenia coli and uterine smooth muscle in that it is abundantly innervated by adrenergic fibers of the hypogastric nerve (Merrillees et al. 1963). One can stimulate this tissue by three different ways. The first is direct stimulation of the hypogastric nerve. The second is weak field stimulation (around $2 \mathrm{~V} / \mathrm{cm}, 50 \mathrm{hz}$ ) which mainly affects intramural adrenergic terminals. The third is a stronger electrical stimulation (above 4-5 $\mathrm{V} / \mathrm{cm}$ ) or long lasting dc pulse which stimulates directly muscle cells.

In the first experiment, vas deferens was stimulated through the hypogastric nerve (pulse frequency $50 \mathrm{hz}$, pulse duration $1 \mathrm{msec}$ ) and $C B$ was applied. CB caused significant inhibition of contraction and this was recovered by wash out (Fig. 4-A). Quite similar results were obtained by $2 \mathrm{~V} / \mathrm{cm}$ ac field stimulation (Fig. 4-B). From these two experiments, it is clear that weak field stimulation gives just the same response as that by direct nerve stimulation and one cannot demonstrate separate response of nerve or muscle by this stimulation. The third experiment was done on TTX pretreated preparations in a similar way as was done on other tissues.

Application of $1 \times 10^{-8} \mathrm{~g} / \mathrm{ml}$ TTX completely abolished contractions produced 


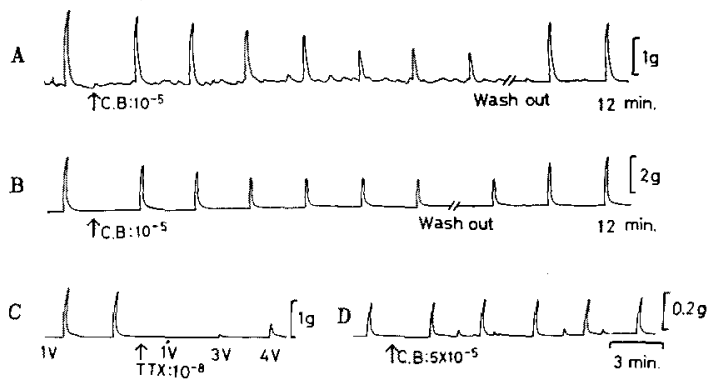

Fig. 4. Contractile response of guinea pig vas deferens.

A: Contraction elicited by electrical stimulation of hypogastric nerve.

$\mathrm{B}$ : Contraction by $\mathrm{IV} / \mathrm{cm}$ ac field stimulation. In both $\mathrm{A}$ and $\mathrm{B}, \mathrm{CB}\left(1 \times 10^{-5} \mathrm{~g} /\right.$ $\mathrm{ml}$ ) caused reversible inhibition of contraction.

C: Effect of TTX on field stimulation. When $1 \times 10^{-8} \mathrm{~g} / \mathrm{ml}$ TTX was applied, contraction by electrical stimulation of $1 \mathrm{~V} / \mathrm{cm}$ disappeared. By increasing the stimulation strength to 3 and $4 \mathrm{~V} / \mathrm{cm}$, small contractions reappeared.

D: Continuous record of C. Stimulus strength $4 \mathrm{~V} / \mathrm{cm}$. Note the sensitivity of tension was increased in this record. $\mathrm{CB}\left(5 \times 10^{-5} \mathrm{~g} / \mathrm{ml}\right)$ had no effect on this preparation even after $30 \mathrm{~min}$ of drug application.

by weak ac field stimulation (1-2 V/cm), but when the stimulus strength was increased to $4-5 \mathrm{~V} / \mathrm{cm}$, small contractions reappeared (Fig. 4-C). This contraction is attributable to the direct stimulation of smooth muscle cells, since the activity of intrinsic nerve had been already blocked by TTX.

Application of CB (10 to $50 \mu \mathrm{g} / \mathrm{ml})$ on this nerve-blocked vas deferens showed no inhibition (Fig. 4-D). On the contrary, there was sometimes rather slight augmentation of contraction heights. In this respect, the smooth muscle of vas deferens is quite different from taenia coli and myometrium. The inhibitory action of $\mathrm{CB}$ on vas deferens is mainly exerted through inhibition of intrinsic nerve fibers. Probably the nature of this inhibition is at the level of transmitter release at adrenergic nerve terminals.

\section{Discussion}

There seems to be a considerable controversy as to the action of cytochalasin $\mathrm{B}$ on contractile tissues. There are papers reporting ineffectiveness of $\mathrm{CB}$ on muscular contraction. For instance, Lash et al. (1970) reported that CB did not affect the contraction of ascidian smooth, cardiac and striated muscles although tail resorption was reversibly inhibited. Sanger et al. (1971) observed that on chick embryonic skeletal muscle in tissue culture, CB did not stop the spontaneous contraction, and they concluded that CB does not noticeably affect the function of actin filaments in myogenic cells. Also in vitro approach of Forer et al. (1972) showed that $\mathrm{CB}$ had no effect on several biochemical binding properties of extracted actin from rabbit skeletal muscle.

On the other hand, Wessells et al. (1971) showed that CB caused cessation of spontaneous contractions of mouse embryonic cardiac muscle in organ culture and 
of dissociated heart cells of chick embryo. He also noted that in intestinal smooth muscle of embryonic mouse and of urechis caupo trochophore larvae, CB reversibly ceased peristaltic contractions. Manasek et al. (1972) reported that CB reversibly disrupted developing myofibrils of early embryonic chick hearts and caused reversible arrest of the embryonic heart beat.

One would notice in reviewing these reports that all these experiments were carried out on primitive or embryonic tissues in an early developmental stage, and there has been no attempt at examining the effect of $\mathrm{CB}$ on adult musele with precise tension measurement which was developed by electrical stimulation.

The present experiment showed clearly that electrically induced contraction of smooth muscle tissues of taenia coli, uterus and vas deferens were all susceptible to CB. The contradictory results of prior reports may be partly due to the lack of precise tension measurement. We believe that it is difficult to estimate any effect of drug on contraction without quantitative tension measurement especially when the effect is very slight.

The next question is whether this inhibitory effect of $C B$ on these smooth muscle tissues is direct inhibition of contractile filament system or indirect inhibition of transmitter release at the intramural autonomic nerve terminals. As is well known, smooth muscle preparations are usually very abundantly supplied with autonomic nerves and in some tissues, the dependency of smooth muscle cells to these nerves is quite strong as is the case with vas deferens.

Since there are an increasing number of evidences that CB inhibits secretory process of various cells (Schofield 1971; Orci et al. 1972; Orr et al. 1972), it might as well be possible that CB inhibits the transmitter release at the nerve terminals of smooth muscle tissues. To clarify this point, tetrodotoxin was used. In the presence of adequate amount of TTX, one can suppress virtually all activities of intramural nerve fibers and elicit selectively the response of smooth muscle cells.

In taenia coli and rat uterus, inhibitory action of CB in the presence of TTX was completely the same as was in control experiments. From this it was concluded that in both tissues, CB exerts inhibitory effect directly on smooth muscle cells, and intrinsic nerves have little role in this effect.

In vas deferens, the situation is different. After TTX application, contractile response to weak electrical stimulation disappeared completely and after the stimulus strength was increased two to three fold, weak muscle response reappeared. This sequence shows clearly the blockage of intrinsic nerve activity by TTX.

Cytochalasin B did not inhibit this myogenic contraction even at five times the standard dose $(50 \mu \mathrm{g} / \mathrm{ml})$. In this respect, smooth muscle of vas deferens seems different from other tissues. It needs further elucidation whether this is a phenomenon characteristic of vas deferens smooth muscle or a result of increased stimulus which might provoke non-specific smooth muscle reaction which is insensitive to CB.

Recently Zigmond and Hirsh (1972) reported that CB reversibly inhibited lactate production and glucose utilization in horse and rabbit leucocytes and 
showed that this inhibition was induced through the blockage of glucose uptake into the cells resulting in suppression of glycolysis. Smooth muscle contraction is energy dependent, and the possibility that the action of $\mathrm{CB}$ on smooth muscle is due to a metabolic inhibition could not be ruled out. We have tested this point by comparing the pattern of contraction inhibition by metabolic inhibitors with that by cytochalasin $B$.

Both in glucose-free solution and in the presence of $5 \times 10^{-5} \mathrm{~g} / \mathrm{ml}$ monoiodoacetic acid, taenia coli showed initial phase of increased contraction which lasted about 10 to $15 \mathrm{~min}$, and then contraction started to decrease gradually and reached a steady level. The recovery in normal Krebs solution was very rapid in glucosefree experiment, but was slow in monoiodoacetic acid experiment, taking about 2 hrs. In the case of dinitrophenol $\left(1 \times 10^{-6}\right.$ to $\left.1 \times 10^{-5} \mathrm{~g} / \mathrm{ml}\right)$, the inhibition started as soon as the drug was applied and was not reversible. In short, the time course of suppression of smooth muscle contraction by metabolic inhibition was quite different from inhibition of contraction by cytochalasin B.

At present, the nature of contraction inhibition by $\mathrm{CB}$ seems to be most probably the direct inhibition of contractile filament system, at least in the smooth muscle of taenia coli and in myometrium. Further electron microscopic examination is needed to clarify whether this is due to the disruption of contractile filaments in these cells.

Note added in proof; Since submission of this manuscript, there appeared a paper which showed cytochalasin $B$ effectively inhibited the norepinephrine release from hypogastrie nerve endings of the guinea pig vas deferens (Thoa, N.B. et al., (1972), Proc. nat. Acad. Sci. (Wash.), 69, 520-522).

\section{References}

1) Allison, A.C., Davies, P. \& De Petris, S. (1971) Pole of contractile microfilaments in macrophage movement and endocytosis. Nature, New Biol., 232, 153-155.

2) Burnstock, G. (1970) Structure of smooth muscle and its innervation. In Smooth Muscle. edited by E. Bülbring et al, Edward-Arnold Ltd., London, pp. 1-69.

3) Carter, S.B. (1967) Effects of eytochalasins on mammalian cells. Nature, 213, 261264.

4) Forer, A., Emmerson, J. \& Behnke, O. (1972) Cytochalasin B: Does it affect actinlike filaments?. Science, 175, 774-776.

5) Ishikawa, H., Bischoff, R. \& Holtzer, H. (1969) Formation of arrowhead complexes with heavy meromyosin in a variety of cell types. $J$. Cell Biol, 43, 312-328.

6) Kuriyama, H,, Osa, T. \& Toida, N. (1966) Effects of tetrodotoxin on smooth muscle cells of the guinea pig taenia coli. Brit. J. Pharmacol. Chemother., 27, 366-376.

7) Lash, J., Cloney, R.A. \& Minor, R.R. (1970) Tail resorption in ascidians: Effects of cytochalasin B. Biol. Bull. Mar. Proc. Lab. Woods Hole Mass., 139, 427.

8) Manasek, F.J., Burnside, B. \& Stroman, J. (1972) The sensitivity of developing cardiac myofibrils to cytochalasin B. Proc. nat. Acad. Sci. (Wash.), 69, 308-312.

9) Merrillees, N.C.R., Burnstock, G. \& Holman, M.E. (1963) Correlation of fine structure and physiology of the innervation of smooth muscle in the guinea pig vas deferens. J. Cell Biol., 19, 529-550.

10) Orei, L., Gabbay, K.H. \& Malaisse, W.J. (1972) Pancreatic beta-cell web: Its possible role in insulin secretion. Science, 175, 1128-1130. 
11) Orr, T.S.C., Hall, D.E. \& Allison, A.C. (1972) Role of contractile microfilaments in the release of histamine from mast cells. Nature, 236, 350-351.

12) Sanger, J.W., Holtzer, S. \& Holtzer, H. (1971) Effects of cytochalasin B on muscle cells in tissue culture. Nature, New Biol., 229, 121-123.

13) Schofield, J.G. (1971) Cytochalasin B and release of growth hormone. Nature, New Biol., 234, 215-216.

14) Schroeder, T.E. (1970) The contractile ring: I. Fine structure of dividing mammalian (Hela) cells and the effects of cytochalasin B. Z. Zellforsch, 109, 431-449.

15) Wessells, N.K., Spooner, B.S., Ash. J.F., Bradley, M.O., Luduena, M.A., Taylor, E.L., Wrenn, J.T. \& Yamada, K.M. (1971) Microfilaments in cellular and developmental processes. Science, 171, 135-143.

16) Zigmond, S.H. \& Hirsh, J.G. (1972) Cytochalasin B: Inhibition of D-2-deoxyglucose transport into leucocytes and fibroblasts. Science, 176, 1432-1434. 